\title{
Typology as a Theory Building Tool in Management
}

Seyed Mohammad Arabi

Department of Human Resource Management, Faculty of Management, University of Tehran, Iran smarabi444@gmail.com

Saleh Rahimi

PHD Candidate, Department of Human Resource Management, Faculty of Management, University of Tehran, Iran

s.rahimi45@gmail.com

\section{Editor Científico: José Edson Lara}

Organização Comitê Científico

Double Blind Review pelo SEER/OJS

Recebido em 30.09.2019

Aprovado em 29.03.2020 


\begin{abstract}
Classification (in general) and typology (in particular) are processes that run in all aspects of human life. Human beings are daily confronted with multiple and varied data, and in order to accelerate decision-making, categorize amorphous data, organize their environment, and respond to external stimuli based on knowledge of each category. the purpose of classification is ultimately to obtain a typology or taxonomy. Typology alone is not a research method, and in most of the studies reviewed there has been an auxiliary tool alongside formal research methods. The tendency to use quantitative methods as auxiliary methods of typology is surprising, since we have introduced typology as a concept-based method, while most of the methods used to construct those methods are quantitative. This suggests that there is not yet a complete consensus on the typology of construction. Transparency in typology construction methods can lead to greater use of typology.
\end{abstract}

Keywords: Typology; Classification; Management; Theory Building.

\title{
Tipologia como ferramenta de construção de teorias em gerenciamento
}

\section{Resumo}

Classificação (em geral) e tipologia (em particular) são processos que ocorrem em todos os aspectos da vida humana. Os seres humanos são diariamente confrontados com dados múltiplos e variados e, a fim de acelerar a tomada de decisões, categorizar dados amorfos, organizar seu ambiente e responder a estímulos externos com base no conhecimento de cada categoria. o objetivo da classificação é, em última análise, obter uma tipologia ou taxonomia. A tipologia por si só não é um método de pesquisa e, na maioria dos estudos revisados, houve uma ferramenta auxiliar juntamente com os métodos formais de pesquisa. A tendência de usar métodos quantitativos como métodos auxiliares de tipologia é surpreendente, uma vez que introduzimos a tipologia como um método baseado em conceito, enquanto a maioria dos métodos usados para construir esses métodos é quantitativa. Isso sugere que ainda não existe um consenso completo sobre a tipologia da construção. A transparência nos métodos de construção da tipologia pode levar a um maior uso da tipologia.

Palavras-chave: Tipologia; Classificação; Gestão; Edifício da teoria.

\section{Introduction and theoretical contributions}

Classification (in general) and typology (in particular) are processes that run in all aspects of human life. Human beings are daily confronted with multiple and varied data, and in order to accelerate decision-making, categorize amorphous data, organize their environment, and respond to external stimuli based on knowledge of each category. According to Croeson (1970) who is a renowned biologist, the classification of objects and subjects is perhaps the most fundamental and prominent activity of the human mind, and essentially of all forms of science. From this point of view, one should say that classes and species are tools of analysis for humans 
and are the main ways of more recognition. Species and typology exist at any place and at any time, both in human social life and in the academic literature of social sciences. Everyone uses it, but almost no one cares about how it is made and the nature of its structure. (McKinney, 1969). For Collier (2012), typology is an analysis tool in the social sciences and can be used in conceptualizing, exploring, and constructing different dimensions (Collier, et al., 2012). According to Delbridge (2013), typology is a key way to organize complex networks and their causal relationships (Delbridge \& Fiss, 2013). Typology in the science of management and organization is also a popular approach to thinking about the types of organizations, structures, and strategies (Doty, et al., 1994). One of the reasons for popularity of typologies is their ability to simplify difficult and complex social science concepts. This is why typology has emerged as a tool for Theory Building in social sciences.

\section{Classification}

Classification is widely recognized as an essential step in understanding a research area. Organizational analysis is also fraught with attempts for conceptual classifications of the organization (Meyer, et al., 1993). Bailey (2005) classifies the process of grouping phenomena on the basis of similarity. For McClowe (1978), classification is the process of identifying and formally assigning different forms of organization to known categories, specifically in management and organization science (McKinney, 1969). The aim is that the phenomena within each class have the most similarity and the least difference with each other, as well as for the comparison between the classes, each class has the the most difference with other classes (Doty \& Glick, 1994). Classification reinforces this principle of organization theory that many of the functional aspects of different organizations are dependent on the type and kind of organization. For Meyer and his colleagues, the basis of all these and other classification schemes is the attempt to understand organizational diversity through typology and taxonomy (Meyer, et al., 1993). In fact, the purpose of each classification is ultimately one of the types of typology or taxonomy that will be explained below.

\section{Typology and Taxonomy}

As mentioned in the preceding section, the purpose of classification is ultimately to obtain a typology or taxonomy. Although some people believe that there is no difference between the two and sometimes use them as one another, others believe that there are significant 
and meaningful differences between them. The main difference is in how they are used and referenced. Most scholars refer to schemas derived from the concept as typology and schemes derived from experience as taxonomy (Hambrick, 1984) (Collier, 2008) (Bailey, 1994).

But there is another difference between typology and other methods of classification. According to Doty and Glick (1994) typology, unlike classification systems, is not merely a tool for categorizing phenomena into unique and comprehensive groups. Rather, typology is an interrelated set of ideal species that can predict changes in dependent variables (Doty \& Glick, 1994) (Reiche, et al., 2017). In fact, what separates typology from a simple classification is, in addition to its conceptualization, the existence of a typological relation to a dependent variable. From Doty's perspective, classification and typology each are a categorization system and order in which topics and phenomena are grouped into individual groups based on a set of decision rules and regulations. But in taxonomy, ideal species are based on a unique combination of defined traits and characteristics, and the proximity of empirical phenomena to ideal species determines the rate of dependent variable (Doty \& Glick, 1994) (O'Raghallaigh, et al., 2010). Examples of management theories can be provided for greater transparency. Joan Woodward's classification of organization technology (unit production, mass production, and process production) is a simple classification, neither typology nor taxonomy. The results of Charles Perrow's research on organizational technology have led to four technologies (engineering, artistic, repetitive and non-repetitive) based on two dimensions of Modifiability and Task Analyzability. This is an example of a taxonomy based on empirical findings. Similar to any of the types provided by Charles Perrow can be observed in real-world organizations, but the framework of Miles and Snow's strategy or Michael Porter's generic strategy are considered as typology. Because in addition to classifying the subject of the strategy according to related concepts, it is also capable of predicting a dependent variable (such as organizational performance). Strategies of defender, attacker, passive and analyst are each an ideal species. Accordingly, and based on the definition of typology, it is difficult to find an organization in the real environment with a strategy of mentioned types (in all respects), but the organizational performance can be predicted by approaching more to each ideal species.

A brief comparison of typology and taxonomy in the following table makes the differences between the two quite clear; 
Table 1. Comparison of typology and taxonomy based on (Lambert, 2015) (Bailey, 2005) (Yavari \& Shams-ul-Sadat, 2013)

\begin{tabular}{|l|l|}
\hline \multicolumn{1}{|c|}{ Taxonomy } & \multicolumn{1}{|c|}{ Typology } \\
\hline The Product of Empiricism Philosophy & The Product of The Philosophy of Essence of Nature \\
\hline More Empirically & More Conceptually \\
\hline $\begin{array}{l}\text { Classes (Taxonomic Rank) Derived from The } \\
\text { Experience }\end{array}$ & Concept-Derived Classes (Species) \\
\hline Much Number of Desired Features & Low Number of Desired Features \\
\hline Deductive Reasoning & Analogy Reasoning \\
\hline Classification by Quantitative Methods & Classification by Qualitative Methods \\
\hline Based on Paired Comparison & Based on Basis Comparison \\
\hline Often in The Empirical Sciences & Often in The Social Sciences \\
\hline Often Hierarchical and Evolutionary & Unique and Diverse Species \\
\hline $\begin{array}{l}\text { Without Defining A Relation with A Dependent } \\
\text { Variable }\end{array}$ & Defining A Relationship with A Dependent Variable \\
\hline
\end{tabular}

\section{Typology components}

According to Collier (2008) a typology has four main parts

A) Comprehensive concept:

The first part of any typology is a concept as measured by typology. That is, it should be clear at the beginning of the typology what is the purpose and meaning on which the typology is based. For example, the human resource (HR) strategy and the organization strategies are comprehensive concept, respectively in Bamberger and Meshoulam (2000), and in Porter's typology.

B) Typology dimensions or variables of row and column:

These variables cross wisely form the main typology matrix. For example, HR strategies in Bamberger's typology are considered as one variable, and the attention to internal or external organization as another variable.

C) Matrix:

The intersection of two variables forms the row and column of matrix. The familiar form of typology is a (2 in 2) matrix resulting from the intersection of two variables with two dimensions. However, row and column variables may have more poles, which will increase the number of matrix cells.

D) Species:

Species eventually settle in matrix cells and contain specimens and typology content, and are named for better understanding. Species make sense to cells derived from the matrix. For example, in Bamberger's typology, species are called paternal, committed, and so on. 
Doty (1994) also cites another part for typology called the fifth part of any typology:

E) dependent variable:

Dotty (1994) believes that typology can play a role in constructing a theory that can make a hypothesis based on similarity to model species. In the typology of Bamberger and Meshoulam (2000), the closer proximity to each of the four ideal species can lead to greater success for the organization. Organizational success in the Miles and Snow typologies as well as in Mintzberg is also seen as a dependent variable, but other variables can be addressed.

\section{Typology as a tool for theory building}

There are many ways to theorize, but there seem to be relatively few of these forms in management. In the current management perspective, the most important issue in this area is the continued dominance of what Abbott (1988) calls "general linear reality" and Ragin (2008) the correlation of "pure effects of thinking". These theoretical approaches tend to examine the social world (as well as the organization) mainly in terms of linear relationships and present the form of the correlation "The more X, the more $\mathrm{Y}$ ". This use of linear relationships between social and organizational phenomena may be useful, but it is overused in management research, and subjecting the theoretical explanation of phenomena to this method can separate us from systematic and comprehensive description of complexity of phenomena (Delbridge \& Fiss, 2013). The point is not that the correlation approach may not be a good approach to social phenomena, but rather that it is overused and sometimes inappropriate. Theoretical management researches tend to reduced diversity in its approaches. In fact, management theories are diverged from a variety of approaches and are based on a series of fixed and iterative methods (Delbridge \& Fiss, 2013).

Unlike dual and multiple solidarity relationships, typology is a key way to organize complex networks of causal relationships. Through the tool of typology, in addition to classification, a network of causal relationships between phenomena can be described simultaneously.

Typology is an important tool for theoretically distinguishing between the elements of a complex phenomenon, whether social phenomena in general or organizational and managerial issues in particular. This is especially relevant for emerging topics and phenomena that do not yet have a systematic classification of its main elements (Reiche, et al., 2017).

Despite this typology capability, some scholars do not accept it as a theory or a systematic method of theorizing, and regard it as merely a non-systematic classification based on the 
researcher's taste for simplification. Some scholars also see typology as a unique tool for theory building (Doty \& Glick, 1994) (O'Raghallaigh, et al., 2010) (Fiss, 2011). In the configuration approach in management and organization analytics, typology is also widely used. The configuration approach is to configure each set or system of multidimensional features and concepts that are common to each other.

Assuming that typologies are theories, they must have the minimal features to be as a theory. In general, theory building has three main purposes: Description, Explanation and Prediction. In general, typologies are very useful for describing and predicting (Snow \& Ketchen, 2014). Although there is no comprehensive and precise definition of the theory, what is agreed by the theoretical experts are the three basic features. First, structures must exist in theory and be properly defined. Second, the relationship between these structures must be specified and, ultimately, the relationships between the constructs must be flexible (Doty \& Glick, 1994).

\section{1- Structures in typology}

An accurate typology has the first condition of being a theory. Because differences, relationships and integration of important concepts are well illustrated (Niknazar \& Bourgault, 2017). According to Doty (1994) in typology we have two types of structures. The first is the ideal variant, and second, the two-dimensional structures. Ideal species are complex structures formed from a comprehensive mix of multiple structures. Ideal variant is not a hypothesis, but it does provide some guidance on how to construct a hypothesis. In fact, the similarity of phenomena to ideal variant and changes of dependent variable is the basis of hypotheses in typology. For example, Miles and Snow identified three types of organizations as ideal species that are most effective. In fact, the effectiveness of organizations is as a dependent variable, and the ideal species are somehow related to the dependent variable (Doty \& Glick, 1994).

The inclusion of the ideal type in typology has at least two implications for typology theories. First, the ideal type represents the types of organizations that "must exist", not necessarily those that "exist". For this reason, the empirical sample of the organizational ideal species must be very scarce or virtually non-existent. The second, ideal species are complex phenomena that must be described through multidimensional variables and properties. As a result of these two consequences, it should not be assumed that the ideal species is a different 
set of phenomena, but that the ideal species provides a unique combination of dimensions used to describe the phenomena.

The second structure in typology consists of the dimensions or variables of row and column, that define the ideal species. For example, in the typology of the HR strategies of Bamberger and Meshoulam, two structures of control and attention have been used. Both of these structures are dependent variables in traditional theories that describe the change in dependent variables, but are analyzed together in this typology to evaluate the success of HR strategy (Doty \& Glick, 1994).

\section{2- Relationships between structures}

Typology also fulfills the second condition for being a theory. The relationships between the typological dimensions make the species together, and the hypotheses are constructed based on the relationships between the species and the dependent variable. Unlike most traditional theories, typology theories do not focus on the assumptions between onedimensional constructs and primary variables but typological theories insist on the intrinsic stability between structures and the ideal species and seek to explain why internal typological patterns affect the dependent variable. (Collier, 2008) (Doty \& Glick, 1994)

Thus, typology seeks to evaluate the similarity of the experimental sample to ideal variant with the dependent variable outside of typology. For example, in the work of Mintzberg or Miles and Snow and many similar works in management science, similarity to ideal variant is more effective.

\section{3- Falsifiability}

The last feature of a theory is falsification, which shows whether predictions made with typology can be tested and falsified or not. All discussions about the configuration and predictions of dependent variable should be clearly stated in a testable manner (Niknazar \& Bourgault, 2017). What can be falsifiable in the typology theory is the relationship between the size of phenomenon similarity with the ideal species and the dependent variable. Dotty insists that in order to test the falsifiability of a theory or a typology they must necessarily be a quantitative model. This prediction is falsifiable by measuring the distance between the experimental sample and the ideal species, and then use this deviation to predict the dependent variable behavior (Doty \& Glick, 1994). 
Typology as a theory is much more complex than traditional theories because unlike traditional relationships between two variables, it has the capacity to capture and analyze complex and multiple causal relationships (Niknazar \& Bourgault, 2017). And it can be said that, despite to some scientists, not only is it the basis for constructing a theory (Miller, 1996), typology is a unique form of theory building (Doty \& Glick, 1994). The advantage of typology over traditional theories is that a very clear and explicit typology allows for the creation of a Equifinality. This means that by constructing multiple patterns one can predict the same results in the independent variable for different types. For example, in Miles and Snow's typology, similarity with all three species improves performance (Reiche, et al., 2017).

As a result, a good typology must have the following three characteristics to serve as a theory;

A: Each of the ideal species must be identified and described.

B: The basic structures and criteria used in the construction of species must also be well defined and described in the model.

C: Any other assumptions about the predictive indices of the hypothetical species as well as the related species (due to the combination of different species) should also be seen in the model.

\section{Typology Building Methods}

Contrary to Miller's view that points out there are no specific methods and guidelines for constructing typology, but a survey in the research literature shows that scientists have proposed different methods for constructing typology (Bailey, 1994) (Kluge, 2000) (O'Raghallaigh, et. al., 2010) (Niknazar \& Bourgault, 2017) (Collier, 2008) (Doty \& Glick, 1994). Although these methods differ in detail, they generally have similar steps;

There are various methods and techniques for constructing typology that can be divided into two main frameworks. Qualitative and quantitative methods (Bailey, 2005).

Step One: Define the limits and boundaries of a comprehensive typology theory and its design purpose

Step Two: Identifying the Structures and Independent Variables Affecting the Typology Design and Choosing the Most Important of them as Typological Dimensions

Step Three: Making Ideal Species Based on Selected Structures and Dimensions and defining each ideal species accurately 
Stage Four: Explain the Relationship between Structures by Evaluating and Explaining the Effects of Similarity to Ideal Species and Dependent Variable Variations

Step Five: Evaluate and test the real-world typology-based hypotheses

Each of these steps can be implemented in a variety of ways, as noted by the researchers.

In the first part of current study, the quiddity and quality of typology was studied. Now we will discuss the research questions and the method to answer them.

\section{Research methodology}

Due to the distribution and diversity of studies in the field of typology and the various definitions and inconsistencies reflected in the results of studies, systematic review method was used to answer the research questions. The main features of a systematic review are the high reliability of this type of study and its multi-step or step-by-step approach. A systematic review first examines studies related to the research question, followed by a critical process or methodological quality assessment, and then with the statistical combination of eligible studies or the qualitative combination of these kinds of studies reaches the findings with stronger intuition or higher added value. Systematic review is a powerful tool for studying, analyzing, and combining the findings of relevant studies and ultimately answering the research questions (De Loe et al. 2016).

The research questions that will be answered in this study are:

1. Has the tendency to use typology been increased in management research?

2. To what extent has the research used the correct definition of typology?

3. Can typology singly be plausible as a theory-building method?

One of the methods of conducting systematic review research that has been used in numerous studies is the Okoli and Schabram method (2010). In this study, to perform the step by step systematic review, Okoli and Shabbaram method was used, introduced in 2010 as a valid guide. These steps are: Planning, Selection, Extraction and Execution, respectively. The selection step, which plays an important role in identifying the articles under review, includes the following steps (Okoli \& Schabram, 2010):

Identification: Search for articles in scientific databases, extract them, and then remove duplicates.

Screening: Study the title and abstract of the collected articles and then select relevant articles and remove irrelevant articles 
Re-screening: Study the introduction and conclusion parts of screened articles and subsequent selection of relevant and removal of unrelated articles.

Final Evaluation: Study the collected ones from the previous stage, considering the research objectives and finally, selecting the final papers, as Figure 1.

- Aims of conducting a systematic study; 1) Providing up-to-date overview of the typology method; 2) Extracting all typology methods and techniques used in the articles.

-Identify and retrieve articles from desired sources and databases with keywords: typology, management and removal of duplicates and removal of irrelevant topics

- Study Abstract and Title, Method Study

-Evaluation of articles and selection of articles

\section{Selection}

- Extract the desired information

\section{Extraction}

- Analysis of findings

Figure 1: Guides of the sudy

In a systematic review, setting research goals and questions is an essential step in determining the process of selecting and analyzing of articles. Then articles are selected based on the question(s) raised in the research as well as the purpose of the research. And after several times of measuring and Screening and doing deeper studies in the final stages, the desired result will be achieved. In this study, Scopus database journals were used to search and identify early articles. The Scopus database is chosen because of its better coverage, more comprehensive 
articles and better results. For this purpose, the systematic review began with a search for English articles that used the relevant terms to research in their title, abstract, or keywords. In the first step of the research process, the keyword of "typology" was searched for in the Scopus Database Articles, which resulted in 2516 articles with the conditions mentioned. In the next step, out of the 2516 articles found, articles that were far from the subject of research (management) were removed, and as a result of this filter, the number of articles cited by the research was reduced to 144 .

In re-screening, we set out to study the methodologies used in selected articles (except abstracts and conclusions) so that we can use and evaluate only those articles that have appropriately used the "typology" term. Finally, the number of selected research papers was reduced to 53 after the screening process was completed, based on the subject of study, the research questions and the research method.

Then, based on the research criteria, a database of selected articles was formed. Research criteria are:

- Citation information related to the article including: author(s) name, year of publication, and journal name;

- Number of article citations;

- Field of study;

- The method(s) used and the method(s) mentioned in the article (Figures 2 and 3)

\begin{tabular}{|l|l|r|}
\hline $\begin{array}{c}\text { Steps of the } \\
\text { study } \\
\text { process }\end{array}$ & \multicolumn{1}{|c|}{ The performed process } & $\begin{array}{r}\text { Number of } \\
\text { Remaining } \\
\text { Articles }\end{array}$ \\
\hline Step One & Search on SCUPOS e-resources using the 'Typology' keyword & 2516 \\
\hline Step Two & Search by the keyword 'typology' and screening from 2008 to 2018 & 144 \\
\hline Step Three & Add 'management' keyword in abstract and remove unrelated topics & 53 \\
\hline Step Four & Study articles on the method of application & 53 \\
\hline Step Five & Summary and Conclusion & 53 \\
\hline
\end{tabular}

Figure 2: screening process 


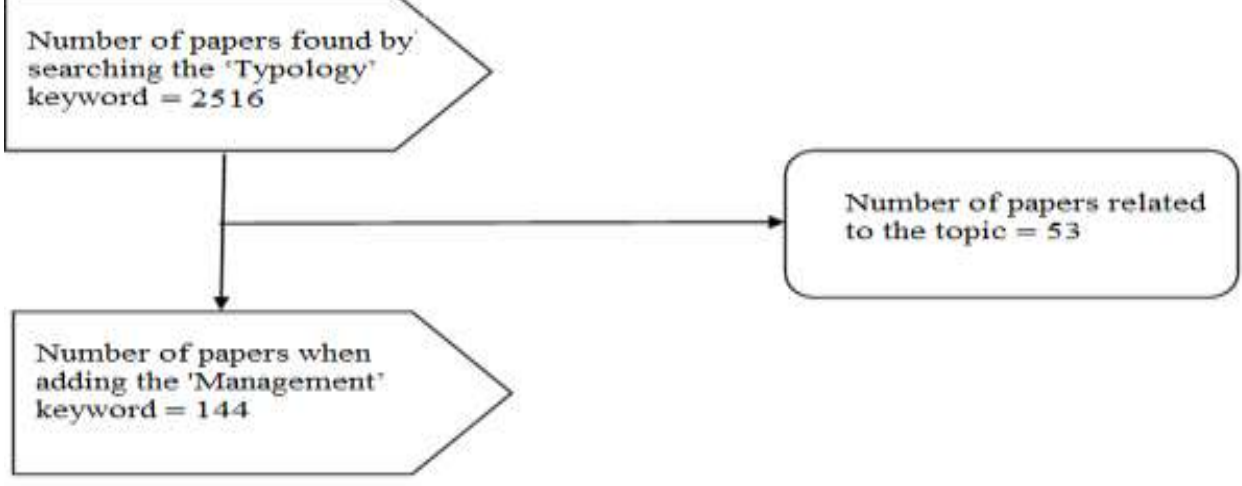

Figure 3: Number of papers

\section{Findings of Research}

In this section, the results of systematic review of 53 selected papers with the aim of answering the research questions are reviewed. In the following we will discuss and review the research findings.

\section{2-1. Findings; Databases}

The reviewed articles are published in 10 databases including Elsevier, Wiley, Sage, Nature, Springer, Taylor, and Francis and Emerald. Diagram 1 shows the databases and their frequency percentage (based on the number of articles extracted). Accordingly, the most reviewed articles were available in the two Elsevier and Wiley databases (Figure 4).

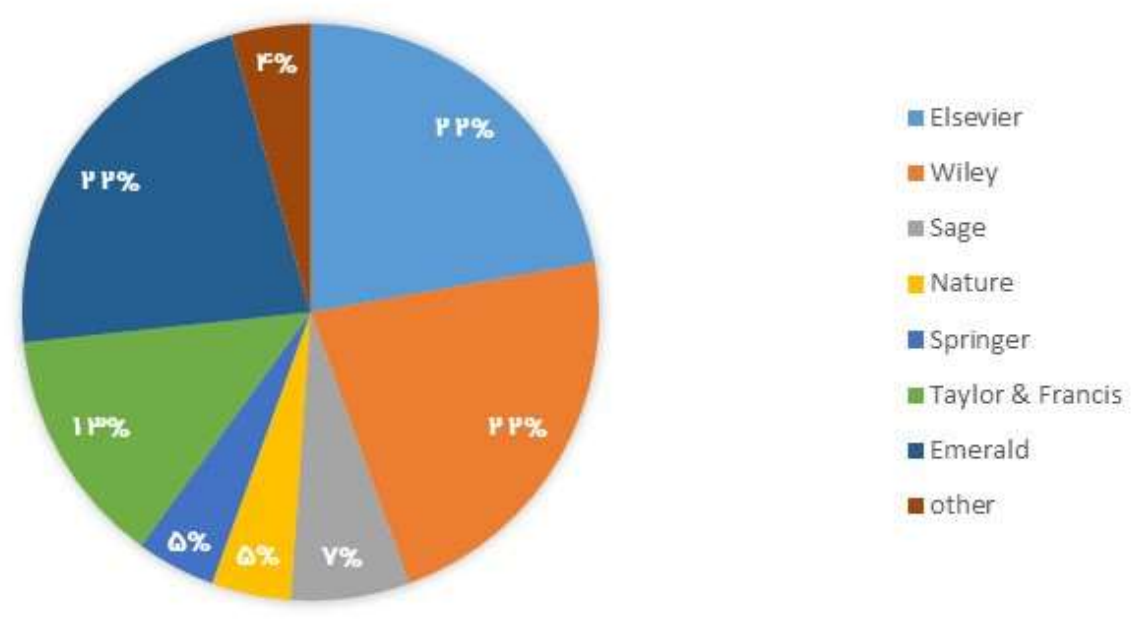

Figure 4 - Name of Scientific Banks and Percentage of Use of Articles Published in them 


\section{2-2. Findings; year of publications}

One of the research questions is to study the trend of attention to typology in recent years. Distribution of the reviewed articles shows that over the 10-year period (2008 to 2018) the trend of using typology has increased. It has been suggested that in recent years the use of typology has increased significantly (Figure 5).

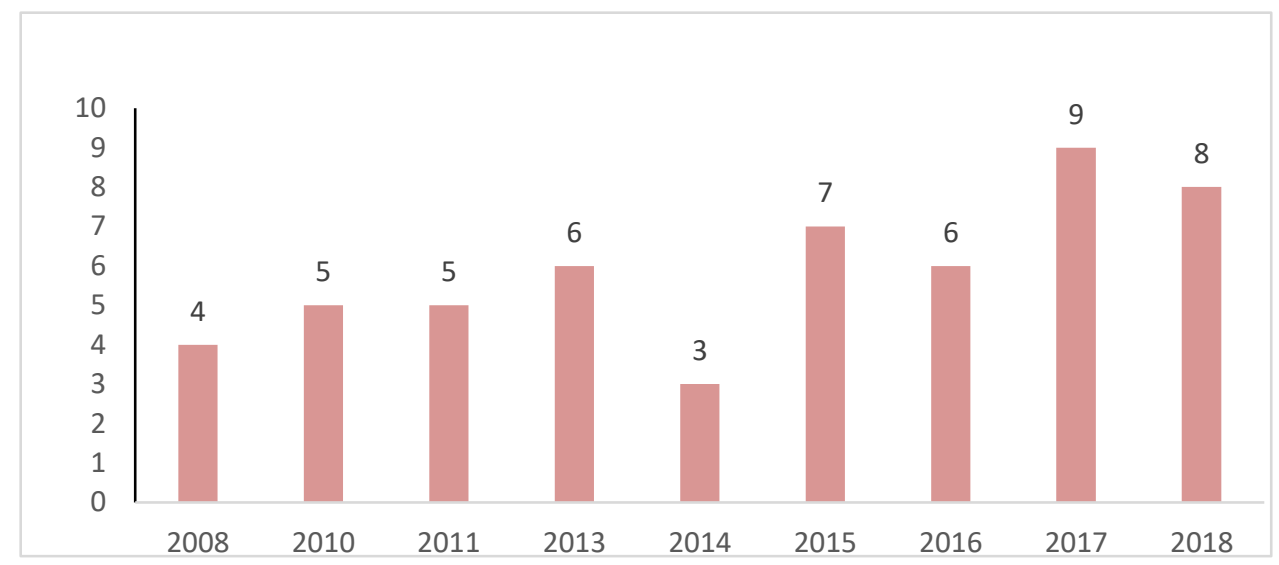

Figure 5 - Sorting the articles of last 10 years by year of publication

According to the distribution of the articles in Chart 2, it can be said that in the last 4 years the use of a variety of typological methods in management-related research has been associated with growth over the previous years.

\section{2-3. Findings; Field of studies}

In the final screening phase of the research papers of the selected articles, 53 selected articles were identified in 11 management-related areas, the most important being product, strategy, management, business, human resources, education, behavior, supply chain, Marketing and innovation pointed out. As shown in Figure 6, most of the research done in the selected articles is in the field of management. 


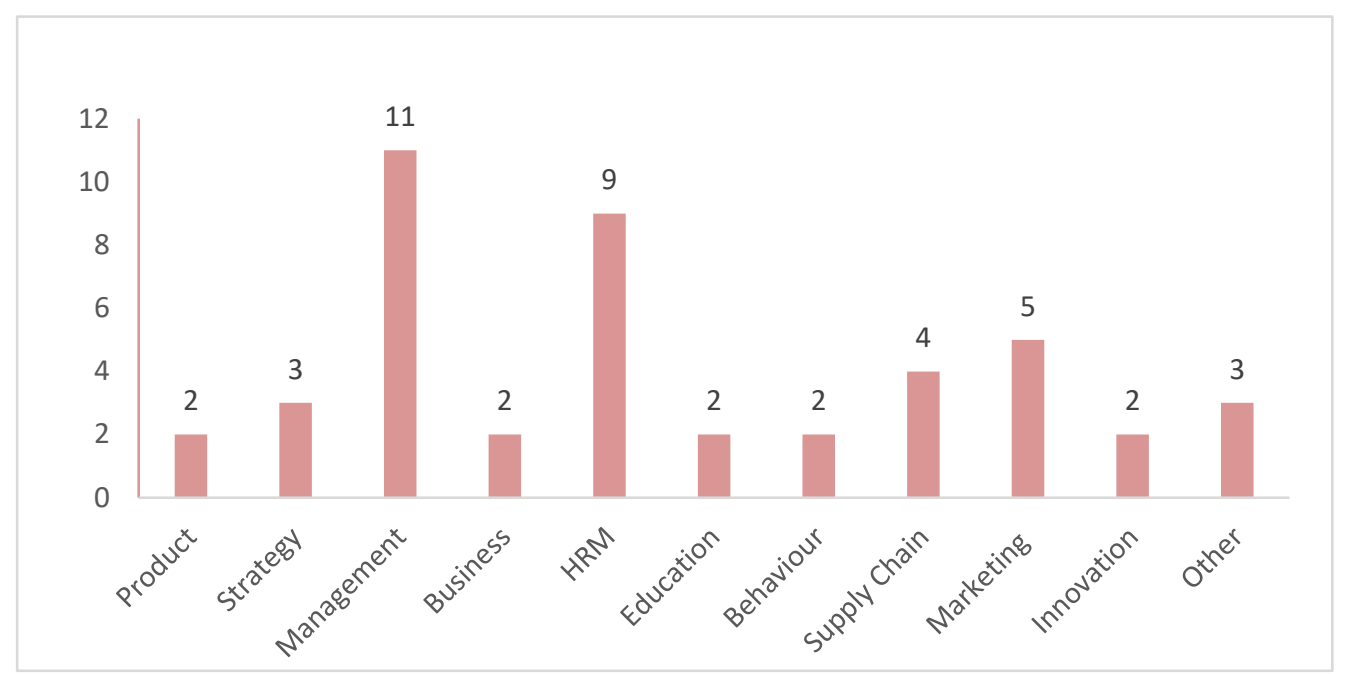

Figure 6: Classification of articles for the last 10 years by field of activity

\section{2-4. Findings; Research Methods}

According to a review of the literature on selected articles, it can be said that in recent years a considerable number of studies have used typology as the main research tool and has been associated with a significant increase. The results show that among all the typological methods, the survey method had the most use. Subsequently, all the typological methods used in these studies were reviewed and categorized. The frequency of use of a variety of typological methods can be seen in the articles reviewed in Figure 7.

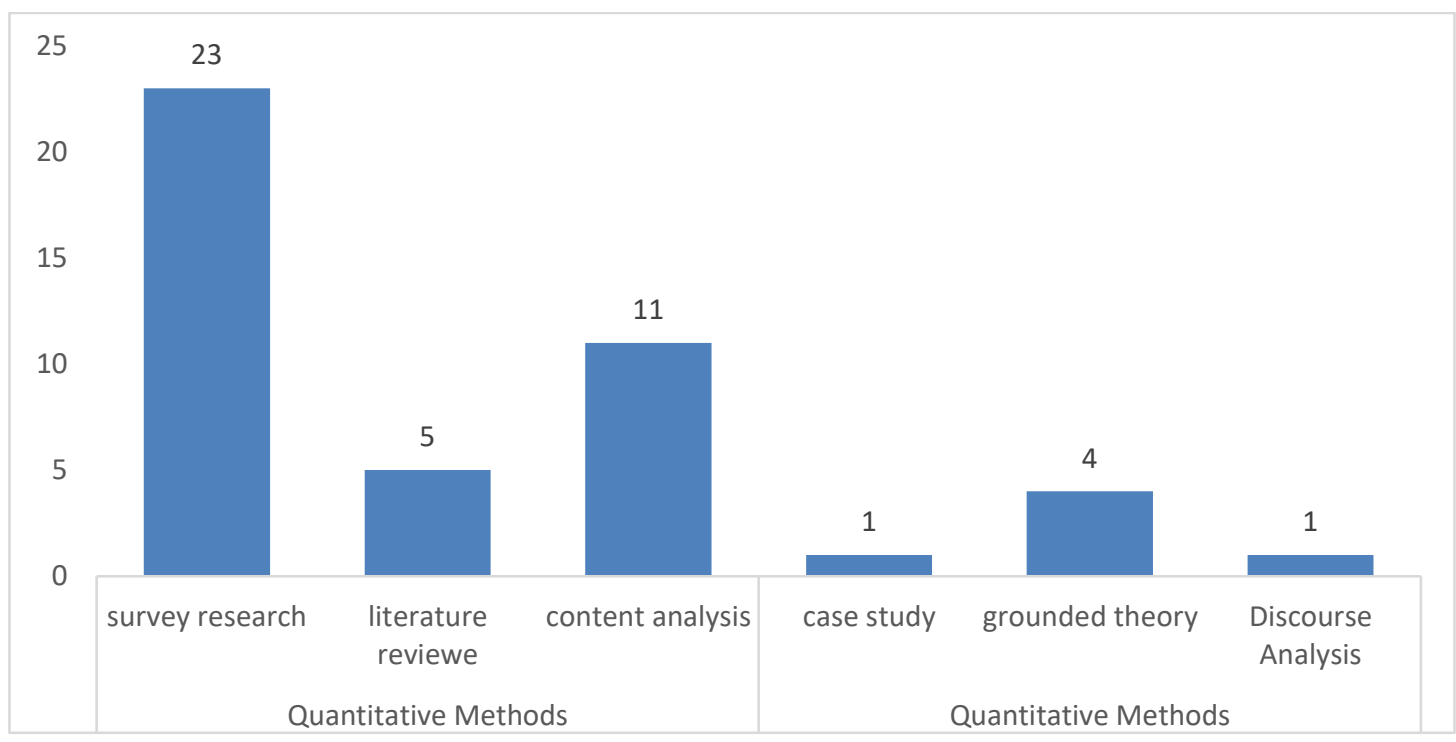

Figure 7: Classification of articles for the last 10 years by research method

According to surveys conducted, research shows that $55 \%$ of existing papers have independent variables and $45 \%$ have dependent variables (Figure 8). 


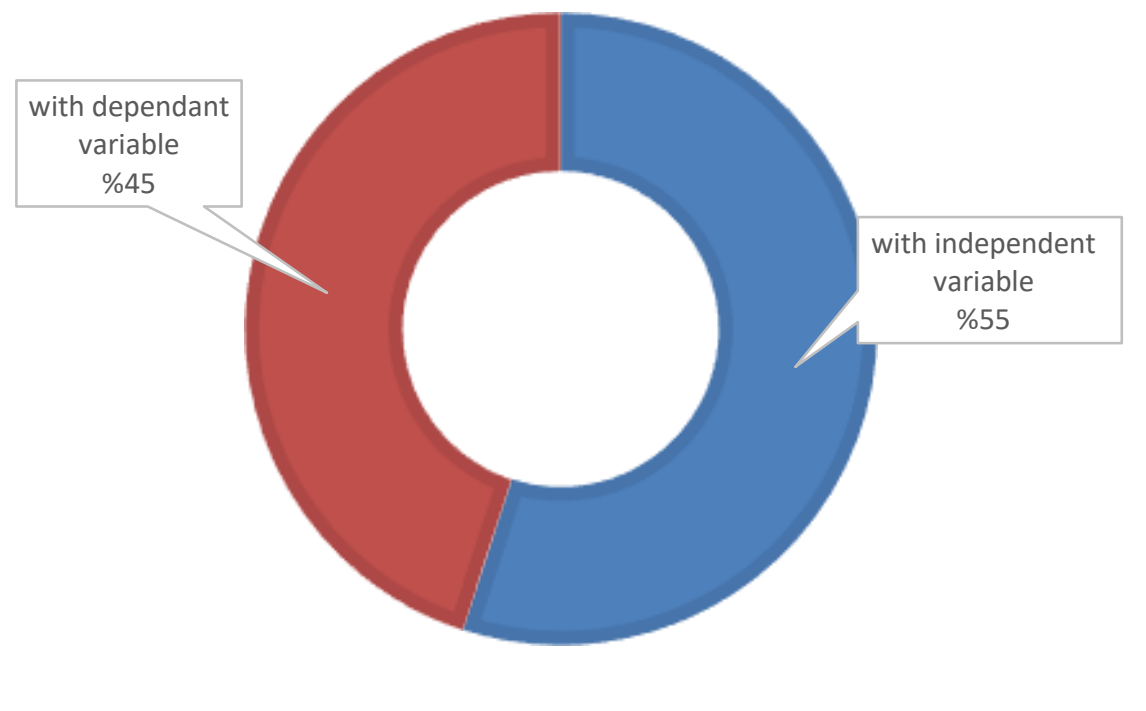

Figure 8: Classification of papers

Typology Typologies

Given the complexity of the concept of typology and the different ways of achieving it, Bailey (2005) presents a typology of different models. Based on two qualitative and quantitative frameworks in the construction of typology as well as empirical and conceptual strategy on the other hand, he places the species of chance into four types. In his view, the types of typologies that have used conceptual strategy are generally in nature and are derived from analogy prior to empirical research. Cell 1 typologies include the ideal species, the made species, and the polar species, and may or may not have clear empirical reference. Even if they are purely theoretical and without empirical evidence, they are still valuable for exploration and development purposes in typology. However, if used experimentally, they are subject to accusations of improper use or false assumptions (Bailey, 2005).

The second type of typology is derived from anthropological research and falls into the outermost layers. While internal and external typologies may have been developed by more specialized individuals, they may be carried out by non-core researchers or even by community and the general public.

In general, the few taxa that are housed in cells 1 and 2 are more restrictive species rather than complete species. Therefore, they can be referred to as decreasing approaches to typology. And there are some examples in this regard, as already mentioned.

Almost all types of typologies are found in cell 4 (quantitative and experimental) and cell types 3 (quantitative and exploratory) are rare, and remember that the term is not present in the typology literature. This type of typology can only refer to batch structures, purely conceptual 
and non-empirical, which are processed through quantitative algorithms. The scope of such analysis and the stability of the resulting species are not exactly known. The outlook for this typology is low. In contrast, in cell type 4 (experimental and quantitative), there is much work. A wide variety of clustering, numerical classification techniques, whether convergent or condensing techniques, or diverging and dividing techniques in clustering, clustering, clustering, and clustering, all fit into cell 4. Clusters and clusters generally do not have any cognition, but can be used as examples in reducing species. They can provide a versatility criterion for the collapse of multiple but continuous cells, and obtain a new cell that has antagonistic properties to its predecessor but with less heterogeneity. They can also be applied to computational assumptions in the process of obtaining the maximum inter-batch similarity at the scale of experimental samples (Bailey, 2005) (Table 2).

\begin{tabular}{|l|l|}
\hline \multicolumn{1}{|c|}{ Conceptual / Exploratory } & \multicolumn{1}{c|}{ Conceptual } \\
\hline 2 species of anthropology & 1 ideal species (qualitative) \\
\hline 4 Clustering & 3 Rare and scarce (quantitative) \\
\hline
\end{tabular}

Table 2: Typology of Typologies (Bailey, 2005)

\section{Summary and Conclusion}

Data from the study show that, contrary to Bill Britt, the tendency to use typology in recent years has not only decreased but also increased. This may be due to management's handling of new complex issues or the ease of use of typology in expressing issues. However, much of the research based on the correct typology does not measure the relationship to a dependent variable, and this may have some drawbacks in theorizing for the typology. But what is clear is that typology alone is not a research method, and in most of the studies reviewed there has been an auxiliary tool alongside formal research methods. The tendency to use quantitative methods as auxiliary methods of typology is surprising, since we have introduced typology as a conceptbased method, while most of the methods used to construct those methods are quantitative. This suggests that there is not yet a complete consensus on the typology of construction. Transparency in typology construction methods can lead to greater use of typology.

\section{References}

Ahlquist, J. S. \& Breunig, C., 2012. Model-based clustering and typologies in the social sciences. Political Analysis, 20(1), pp. 92--112. 
Bailey, K. D., 1984. A three-level measurement model. Quality and Quantity, 18(3), pp. 225--245.

Bailey, K. D., 1988. The conceptualization of validity: Current perspectives. Social Science Research, 17(2), pp. 117--136.

Bailey, K. D., 1994. Typologies and taxonomies: an introduction to classification techniques. s.l.:Sage.

Bailey, K. D., 2005. Typology construction, methods and issues. In: Encyclopedia of social measurement. London: Elsevier, pp. 889-898.

Becker, H., 1940. Constructive typology in the social sciences. American sociological review, 5(1), pp. 40-55.

Bensaou, M. \& Venkatraman, N., 1995. Configurations of interorganizational relationships: A comparison between US and Japanese automakers. Management science, 41(9), pp. 1471-1492.

Breimo, A., 1978. Typology in Social Studies. Pazhouheshkade, 2 (1), pp. 37-42.

Büchel, F. et al., 2016. Building empirical typologies with QCA: Toward a classification of media systems. The International Journal of Press/Politics, 21(2), pp. 209--232.

Collier, D., 2008. Typologies: Forming concepts and creating categorical variables.

Collier, D., LaPorte, J. \& Seawright, J., 2012. Putting typologies to work: Concept formation, measurement, and analytic rigor. Political Research Quarterly, 65(1), pp. 217--232.

Crutzen, N. \& Van Caillie, D., 2010. The Origins of Small Business Failure: A Grounded Typology.

Decrop, A. \& Snelders, D., 2005. A grounded typology of vacation decision-making. Tourism management, 26(2), pp. 121--132.

Delbridge, R. \& Fiss, P., 2013. Styles of theorizing and the social organization of knowledge. Academy of Management Review, pp. amr--2013.

Dess, G. G., Newport, S. \& Rasheed, A. M., 1993. Configuration research in strategic management: Key issues and suggestions. Journal of Management, 19(4), pp. 775--795.

Doty, D. H. \& Glick, W. H., 1994. Typologies as a Unique Form of Theory Building: Toward Improved Understanding and Modeling. The Academy of Management Review, apr, 19(2), pp. 230--251.

Elman, C., 2005. Explanatory typologies in qualitative studies of international politics. s.1.:Cambridge University Press.

Eppler, M. J., Hoffmann, F. \& Pfister, R., 2011. Rigor and relevance in management typologies: Assessing the quality of qualitative classifications. s.1.:mcm institute, University of St. Gallen..

Fiss, P., 2011. Building Better Causal Theories: A Fuzzy Set Approach to Typologies in Organization Research. Academy of Management Journal, 54(2), pp. 393--420.

Fleiß, J., 2010. Paul Lazarsfelds typologische Methode und die Grounded Theory. Generierung und Qualität von Typologien. s.l.:Springer.

Gabor, M. R., 2009. Typological analysis as analysis method of marketing data. s.1.:s.n.

Grävingholt, J., Ziaja, S. \& Kreibaum, M., 2012. State fragility: towards a multidimensional empirical typology. s.l.:s.n.

Hambrick, D. C., 1984. Taxonomic approaches to studying strategy: some conceptual and methodological issues. Journal of Management, 10(1), pp. 27-41.

Jackson, P., 2005. How do we describe coaching? An exploratory development of a typology of coaching based on the accounts of UK-based practitioners. s.l.:s.n.

Ketchen, D. J. et al., 1997. Organizational configurations and performance: A metaanalysis. Academy of Management Journal, 40(1), pp. 223-240. 
Kluge, S., 2000. Empirically Grounded Construction of Types and Typologies in Qualitative Social Research. Qualitative Social Research, 1(1), p. 14.

Lambert, S., 2015. The importance of classification to business model research. s.1.:s.n.

Mamadouh, V. D., 1997. Political culture: a typology grounded on Cultural Theory. GeoJournal, 43(1), pp. 17--25.

Marradi, A., 1990. Classification, typology, taxonomy. s.1.:Springer.

McKelvey, B., 1975. Guidelines for the empirical classification of organizations. Administrative Science Quarterly, pp. 509--525.

McKelvey, B., 1978. Organizational systematics: Taxonomic lessons from biology. Management Science, 24(13), pp. 1428--1440.

McKinney, J. C., 1950. The role of constructive typology in scientific sociological analysis. s.1.:JSTOR.

McKinney, J. C., 1969. Typification, typologies, and sociological theory. Social Forces, 48(1), pp. 1-12.

Merlino, A., 2014. From the analysis of argumentation to the generation of typologies: A model of qualitative data analysis. s.l.:The Qualitative Report.

Meyer, A. D., Tsui, A. D. \& Hining, R. C., 1993. Configurational approaches to organizational analysis. Academy of Management journal, 36(6), pp. 1175-1195.

Miller, D., 1996. Configurations revisited. Strategic management journal, 17(7), pp. 505512.

Mitleton-Kelly, E., 2003. Complex systems and evolutionary perspectives on organisations: the application of complexity theory to organisations. s.l.:Elsevier Science Ltd.

Mofidi Shemirani, S. \& Nikghadam, N., 2013. The typology of cities, ports and islands of southern Iran during the Qajar period with development criteria. Bagh Nazar Scientific Research Quarterly, 10 (26), pp. 59-70.

Niknazar, P. \& Bourgault, M., 2017. Theories for classification vs. classification as theory: Implications of classification and typology for the development of project management theories. s.l.:Elsevier.

Okoli, C. \& Schabram, K., 2010. A guide to conducting a systematic literature review of information systems research. Sprouts: Working Papers on InformationSystems.

O'Raghallaigh, P., Sammon, D. \& Murphy, C., 2010. Theory-building using Typologies A Worked Example of Building a Typology of Knowledge Activities for Innovation. In: A. A. Respício, ed. Bridging the Socio-technical Gap in Decision Support Systems. Amsterdam: IOS Press, pp. 371-382.

Pawar, B. S., 2009. Theory building for hypothesis specification in organizational studies. s.l.:SAGE Publications India.

Read, D. W. \& Russell, G., 1996. A method for taxonomic typology construction and an example: Utilized flakes. s.l.:Cambridge University Press.

Reiche, S., Bird, A. \& Mendenhall, M. E., 2017. Contextualizing leadership: A typology of global leadership roles. Journal of International Business Studies, 48(5), pp. 552-572.

Rich, P., 1992. The organizational taxonomy: Definition and design. s.1.:Academy of Management.

Sanchez, J. C., 1993. The long and thorny way to an organizational taxonomy. Organization Studies, 14(1), pp. 73--92.

Shepherd, D. A. \& Suddaby, R., 2017. Theory building: A review and integration. s.l.:SAGE Publications Sage CA: Los Angeles, CA. 
Snow, C. C. \& Ketchen, D. J., 2014. Typology-driven theorizing: A response to Delbridge and Fiss. s.1.:Academy of Management.

Steinmetz, G., 2012. Sage Publications, Inc. American Sociological Association. Contemporary Sociology, 41(1), pp. 23--26.

Torr, R., 2008. Theoretical Perspectives as Ideal-types: Typologies as Means not Ends. Social Epistemology, 22(2), pp. 145--164.

Ulrich, D. \& McKelvey, B., 1990. General organizational classification: An empirical test using the United States and Japanese electronics industries. s.l.:INFORMS.

Yavari, V. \& Shamsul Sadat, Z., 2013. Designing a Conceptual Model of Organizational Performance Management for Public and Nonprofit Organizations. Strategic Management Thought, 7 (1), pp. 79-122. 